\title{
Asymmetric Chemoenzymatic Reductive Acylation of Ketones Using a Combined Iron Catalyzed Hydrogenation-Racemization and Enzymatic Resolution Cascade
}

\author{
Osama El-Sepelgy, ${ }^{*[a]}$ Aleksandra Brzozowska, ${ }^{[a]}$ and Magnus Rueping ${ }^{*[a, b]}$
}

\begin{abstract}
A general and practical process for the conversion of pro-chiral ketones into the corresponding chiral acetates has been realized. An iron carbonyl complex is reported to catalyze the hydrogenation-dehydrogenation-hydrogenation of prochiral ketones. By merging the iron catalyzed redox reactions with enantioselective enzymatic acylations a wide range of benzylic, aliphatic and (hetero)aromatic ketones as well as diketones, were reductively acylated. The corresponding products were isolated with high yields and enantioselectivities. The use of an iron catalyst together with molecular hydrogen as the hydrogen donor and readily available ethyl acetate as acyl donor make this cascade process highly interesting in terms of both economic value and environmental credentials.
\end{abstract}

Cascade reactions in synthetic chemistry are an attractive approach towards the development of more efficient and sustainable chemical processes. Transformations, involving diverse bond-forming and bond-breaking steps that can be conducted in one operation afford processes simplicity and practicality which minimizes the amount of waste and simplifies the subsequent workup and purification steps. ${ }^{1}$ The greatest achievements in carrying out cascade multistep reactions have been achieved in the field of biochemistry by employing different enzymes. For more than a century, biocatalysis has been employed in the synthesis of numerous non-natural compounds. There has been tremendous development and biocatalysis now plays a crucial role in the production of fine chemicals and pharmaceuticals. ${ }^{2}$ Despite these advances, the combination of metal catalysis or organocatalysis with enzymes in one pot reactions remains highly challenging due to the incompatibility of classical chemical reaction conditions and biotransformations. ${ }^{3}$

The enzymatic kinetic resolution of racemic alcohols is the most commonly employed method in the industrial production of optically pure alcohols. ${ }^{4}$ Although the metal catalyzed dynamic kinetic resolution of alcohols has evolved, transition metal catalysts still need to be used to efficiently promote the racemization of the undesired enantiomer. ${ }^{5,6}$ As a more challenging alternative the direct conversion of pro-chiral ketones into enantiomerically enriched alcohols has been accomplished. ${ }^{6-8}$ Furthermore, a ruthenium/lipase catalytic

[a] Dr. Osama El-Sepelgy, Aleksandra Brzozowska, Prof. Dr. Magnus Rueping

Institute of Organic Chemistry

RWTH Aachen University

Landoltweg 1, 52074 Aachen (Germany)

E-mail: magnus.rueping@rwth-aachen.de

[b] Prof. Dr. M. Rueping

King Abdullah University of Science and Technology (KAUST) KAUST Catalysis Center (KCC), Thuwal, 23955-6900 (Saudi Arabia) system for the synthesis of anti- and syn-1,3-aminoalcohols from the corresponding $\beta$-amino-ketones has been reported. ${ }^{9}$ These protocols, however, are restricted to the use of more expensive ruthenium-based catalysts and typically suffer from long reaction times (2-4 days).

With regard to more economically and ecologically attractive processes new and more efficient multicatalytic systems have to be developed. One possibility would be to replace the traditional rhodium, ruthenium, and iridium hydrogenation catalysts by earth-abundant and cost efficient catalysts. In this context, ironbased complexes have been extensively investigated as catalysts for a wide range of transformations during recent years. $^{10}$

We have recently reported an iron catalysts for the racemization of chiral alcohols by mimicking the action of Fehydrogenases. ${ }^{11}$ However, to date, iron catalysts that are efficiently able to reduce ketones and at the same time catalyze the racemization of alcohols for combination with enzymatic acylations have not been described.

Thus, the development of a successful iron catalyzed hydrogenation-racemization process via a hydrogenationdehydrogenation-hydrogenation sequence and a subsequent coupling to an enzymatic resolution would be a highly desirable process (Scheme 1). In order to achieve such a dual catalysis cascade procedure the iron catalyst must fulfill the requirement of both redox activity and lipase compatibility.

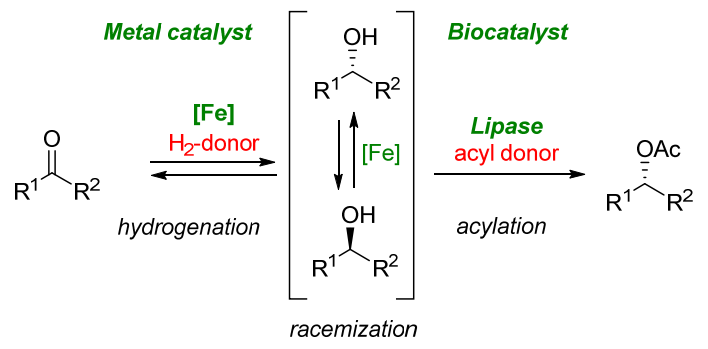
- The first example of noble-metal free cascade reductive acylation of ketones
- The method utilizes inexpensive combined iron and lipase catalysts
- Highly economic and efficient acyl and hydrogen donors

Scheme 1. Iron/lipase catalyzed cascade reaction for the asymmetric reductive acylation of ketones.

With these considerations in mind we decided to investigate the asymmetric reductive acylation of ketones by employing iron complexes for a hydrogenation-racemization-kinetic resolution cascade in the presence of hydrogen, lipase and acyl donors. Herein, we report our initial successful achievements towards an efficient one-pot cascade reaction protocol for the direct conversion of ketones to optically active acetates (Scheme 1). 
Table 1. Combined iron and lipase catalysis for the transformation of acetophenone $\mathbf{2 a}$ into the corresponding chiral acetate $((R)-4 a) .{ }^{\text {[a] }}$

\begin{tabular}{|c|c|c|c|c|c|c|c|}
\hline & $\begin{array}{r}\text { Fe-ca } \\
\text { hydrog } \\
\end{array}$ & $\mathrm{Ph}_{\mathrm{rac}-3}^{\mathrm{OH}}$ & $\begin{array}{c}\text { Lipase } \\
\text { Acyl donor }\end{array}$ & $\overbrace{(R)-4 a}^{O A c}$ & & & \\
\hline Entry & $\mathrm{H}_{2}$ donor & Acyl donor & Lipase (mg) & Toluene (mL) & Temperature & $2 a: 3 a: 4 a^{[b]}$ & $e e[\%]^{[b]}$ \\
\hline 1 & 2,4-dimethyl-3-pentanol (1.5 equiv.) & PCPA (3 equiv.) & 6 & 1 & $90^{\circ} \mathrm{C}$ & $73: 00: 27$ & 96 \\
\hline 2 & $\mathrm{HCOOH}$ (1 equiv.) & PCPA (3 equiv.) & 6 & 1 & $90^{\circ} \mathrm{C}$ & $31: 42: 27$ & 96 \\
\hline 3 & $\mathrm{HCOOH}: \mathrm{Et}_{3} \mathrm{~N}$ (1:1, 1 equiv.) & PCPA (3 equiv.) & 6 & 1 & $90^{\circ} \mathrm{C}$ & $21: 37: 42$ & 48 \\
\hline 4 & $\mathrm{H}_{2}$ (1 bar) & PCPA (3 equiv.) & 6 & 1 & $90^{\circ} \mathrm{C}$ & $02: 26: 73$ & 96 \\
\hline 5 & $\mathrm{H}_{2}$ (1 bar) & EtOAc $(1 \mathrm{~mL})$ & 20 & - & $80^{\circ} \mathrm{C}$ & 02:10:88 & 98 \\
\hline 6 & $\mathrm{H}_{2}$ (1 bar) & $i$-PrOAc (1 mL) & 20 & - & $90^{\circ} \mathrm{C}$ & $02: 15: 83$ & 90 \\
\hline 7 & $\mathrm{H}_{2}$ (1 bar) & EtOAc $(0.5 \mathrm{~mL})$ & 20 & 0.5 & $90^{\circ} \mathrm{C}$ & 04:04:92 & 99 \\
\hline 8 & $\mathrm{H}_{2}$ (1 bar) & EtOAc $(0.5 \mathrm{~mL})$ & 10 & 0.5 & $90^{\circ} \mathrm{C}$ & 01:04:95 & 99 \\
\hline 9 & $\mathrm{H}_{2}$ (1 bar) & EtOAc (0.5 mL) & 6 & 0.5 & $90^{\circ} \mathrm{C}$ & 01:04:95 & 99 \\
\hline 10 & $\mathrm{H}_{2}$ (1 bar) & EtOAc $(0.5 \mathrm{~mL})$ & 10 & 0.5 & $80^{\circ} \mathrm{C}$ & 01:30:69 & 98 \\
\hline $11^{[c)}$ & $\mathrm{H}_{2}$ (1 bar) & EtOAc $(0.5 \mathrm{~mL})$ & 10 & 0.5 & $90^{\circ} \mathrm{C}$ & $12: 10: 78$ & 98 \\
\hline
\end{tabular}

[a] The reactions were performed on a $0.2 \mathrm{mmol}$ scale with iron complex $\mathbf{1}$ (10 mol\%) in a Schlenk tube for $18 \mathrm{~h}$. [b] The ratio of products and ee of $4 \mathrm{a}$ were determined by chiral GC equipped with a $\beta$-dex column. [c] 5 mol\% of iron catalyst.

We began our study with the optimization of a one-pot procedure for the transformation of acetophenone (2a) into the corresponding chiral acetate $(R)-\mathbf{4 a}$. From the different iron catalysts and reaction conditions tested, iron catalyst $1^{11-13}$ was found to be a catalyst which can efficiently reduce ketones to the racemic alcohols and at the same time catalyze the racemization of alcohols. This important finding led us to merge the iron hydrogenation-racemization catalyst with an enzymatic resolution. If successful this would be the case in which an iron catalyst could be applied in a combined hydrogenation or transfer hydrogenation-dynamic kinetic resolution. Hence, we evaluated several enzymes for their compatibility and were pleased to see that the dual catalysis process could be achieved if the lipase from candida antarctica was applied. ${ }^{4}$ Furthermore, several hydrogen donors were evaluated in the presence of $p$ chlorophenyl acetate (PCPA) which acts as an acyl donor for the lipase catalyzed acylation. Using 2,4-dimethyl-3-pentanol, which is a poor acyl acceptor, as a hydrogen source the transfer hydrogenation step was inefficient and $73 \%$ of the acetophenone remained unreacted (Table 1, entry 1). The reduction step was slightly better upon employing 1 equiv. of formic acid as the hydrogen source.

However, the lipase was deactivated and $42 \%$ of the alcohol was not acetylated further (Table 1, entry 2). The use of a 1:1 mixture of triethylamine and formic acid led to poor results in terms of both yield and enantioselectivity (Table 1, entry 3 ). Importantly, after extensive reaction optimization molecular hydrogen showed promising results and the chiral acetate was produced in $73 \%$ yield and $96 \%$ ee (Table 1, entry 4 ). This is an important observation as the dehydrogenation under hydrogen atmosphere is not a favorable process.

The $p$-chlorophenyl acetate cannot be considered as an atom efficient reagent as it produces equivalent amounts of $p$ chlorophenol by-product and needs to be removed by chromatographic separation. Therefore, the use of more efficient acyl donors is a key for the development of more efficient and practical protocols. Interestingly, when toluene was replaced by ethyl acetate the desired product was obtained in higher yield and enantiocontrol $(88 \%, 98 \%$ ee, Table 1, entry 5$)$. The yield and enantioselectivity were unsatisfactory when isopropyl acetate was used as an acyl donor (Table 1, entry 6). Since the rate of hydrogenation and racemization is considerably higher in toluene, a further breakthrough in the yield of $(R)-4 a$ was achieved when the reaction was performed in a 1:1 mixture of toluene and ethyl acetate (Table 1, entry 7 ). Decreasing the amount of lipase (10 or $6 \mathrm{mg} / 0.2 \mathrm{mmol}$ ), provided the chiral acetate $(R)-\mathbf{4 a}$ in high yield of $>95 \%$ and with good stereocontrol of $99 \%$ ee (Table 1, entries 8 and 9 ). A drop in the yield was observed when the iron catalyst loading was reduced to $5 \mathrm{~mol} \%$ or when the reaction temperature was reduced to $80^{\circ} \mathrm{C}$ (Table 1 , entries 10 and 11).

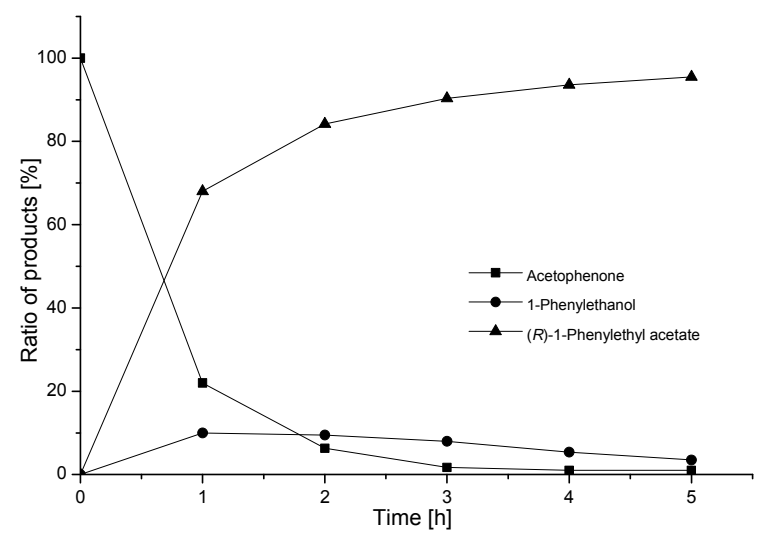

Figure 1.Reaction profile for the reductive acylation of acetophenone (0.2 M) in ethyl acetate/toluene under hydrogen atmosphere. 
Table 2. Direct asymmetric reductive acylation of ketones ${ }^{[a]}$

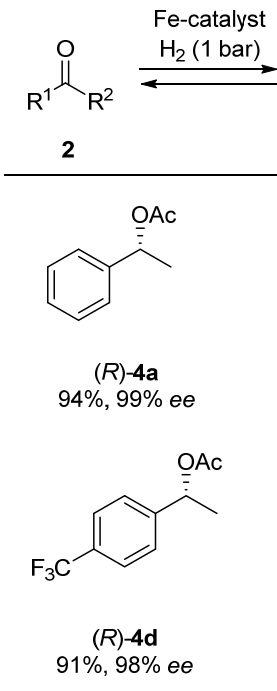

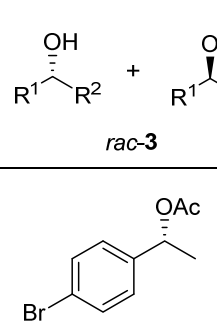

$(R)-\mathbf{4 b}$

$98 \%, 97 \%$ ee<smiles>COc1ccccc1C(C)OC(C)=O</smiles>

$(R)-4 \mathrm{e}$ $88 \%, 99 \%$ ee<smiles>CC(=O)O[C@@H](C)c1ccc(C(C)(C)C)cc1</smiles>

$(R)-\mathbf{4} \mathbf{h}^{b}$ $95 \%, 99 \%$ ee<smiles>CC(=O)O[C@H]1CCc2ccccc21</smiles>

$(R)-4 \mathbf{k}$ $86 \%, 99 \%$ ee $80 \%, 90 \%$ ee<smiles>CC[C@H](OC(C)=O)c1ccccc1</smiles>

(R)-4m $72 \%, 99 \%$ ee<smiles>CC(=O)O[C@@H](C)c1cc2ccccc2o1</smiles>

(R)-4 $\mathbf{p}^{c}$ $95 \%, 95 \%$ ee<smiles>CC(=O)O[C@@H](C)c1ccco1</smiles>

(R)-4n $90 \%, 90 \%$ ee<smiles>CCOCCOC</smiles>

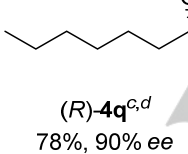

\section{Lipase} $\mathrm{R}^{1} \mathrm{R}^{2}$ (R)-4<smiles>CC(=O)OC(C)c1ccc(F)cc1</smiles>

(R) $-4 \mathrm{c}$ $88 \%, 99 \%$ ee<smiles>COc1cccc(C(C)OC(C)=O)c1</smiles>

$(R)-\mathbf{4 f}$ $95 \%, 96 \%$ ee<smiles>CC(=O)OC(C)c1ccc2c(c1)OCO2</smiles>

(R)-4i $75 \%, 98 \%$ ee<smiles>CC(=O)O[C@H]1CCCc2ccccc21</smiles>

(R)-4! $85 \%, 99 \%$ ee

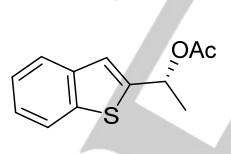

(R) -40 $96 \%, 97 \%$ ee<smiles>CC(=O)OC(C)C1CCCCC1</smiles>

(R) $-4 r^{b}$ $81 \%, 98 \%$ ee EtOAc OAc

[a] Reaction conditions: 2 (0.2 mmol), catalyst 1 (10 mol\%), Novozyme-435 (6 $\mathrm{mg}$ ) in toluene: ethyl acetate $(1: 1,1 \mathrm{~mL})$ were stirred in a Schlenk tube at $90{ }^{\circ} \mathrm{C}$ for $5-8 \mathrm{~h}$; yields after isolation, ee of the acetates were determined by GC equipped with a $\beta$-dex. column; ${ }^{[b]}$ Novozyme-435 (10 mg); ${ }^{[c]}$ Novozyme-435 (3 mg); ${ }^{\text {[d] }}$ Solvent $(0.5 \mathrm{~mL})$.

In order to improve our understanding of the reaction's progress, we studied the kinetics of the reductive acylation of acetophenone in a mixture of ethyl acetate and toluene under 1 bar of hydrogen atmosphere. The distribution of the products as a function of time was recorded (Figure 1). Interestingly, after only $1 \mathrm{~h}, 78 \%$ of the acetophenone was consumed and the chiral acetate was produced in $68 \%$ yield and $>99 \%$ ee. It is also noteworthy that more than $95 \%$ of the $(R)-\mathbf{4 a}$ and only trace amounts of the alcohol and the ketone were obtained after $5 \mathrm{~h}$ at $90{ }^{\circ} \mathrm{C}$. These results indicate that the formation of the ethanol by-product does not interfere with the catalytic process and that this protocol can be utilized for providing rapid access to valuable chiral acetates starting from simple ketones.

With the optimized reaction conditions in hand, we explored the reaction scope. An array of pro-chiral ketones was transformed into the corresponding chiral acetates using our iron/lipase catalytic system (Table 2). In general, aryl methyl ketones were easily converted into chiral acetates using the dual catalytic system. Acetophenone (2a) afforded the corresponding acetate $\mathbf{4 a}$ in $94 \%$ yield with $99 \%$ ee. The application of the electron-deficient ketones $\mathbf{2} \mathbf{b}$-d provided the corresponding acetates in very good yields and enantioselectivities. Similarly, electron-rich chiral acetates $4 \mathrm{e}-\mathrm{i}$ were isolated with high yields and stereoselectivities. Also, good results were obtained with the 2-naphthylmethyl ketone (2j) when the amount of enzyme was reduced. Furthermore, 1-indanone (2k) and 1-tetralone (2I) were converted into the chiral acetates $\mathbf{4 k}$ and $\mathbf{4 l}$ in very good yields and stereocontrol. Ethyl ketone $\mathbf{2 m}$ showed lower reactivity and afforded the product in only $72 \%$ yield. In addition, we found that several heterocyclic derivatives $\mathbf{2 n - p}$ were also tolerated. Importantly, aliphatic ketones, including 2-octanone (2q) and 1cyclohexylethanone $(\mathbf{2 r})$, were converted into the desired acetates in good yields and with high optical purity. It is important to note that the aliphatic ketones are challenging substrates and only few asymmetric reductions afford high enantiocontrol. ${ }^{8 f ; 14}$

Furthermore, as the theoretical maximum yield of the enzymatic resolution of diols 6 is only ca. $25 \%$, we were interested in applying our protocol to the reductive acylation of diketones, which theoretically can afford a single enantiomer. ${ }^{15}$ Pleasingly, the reductive acylation of $\mathbf{5 a}$ and $\mathbf{5 b}$ gave the corresponding enantiomerically enriched diacetates $7 \mathbf{a}$ and $\mathbf{7 b}$ in very good yields. ${ }^{16}$ Also, the 2,5-hexadione (5c) was converted into the corresponding diacetate $7 \mathrm{c}$ in a very high enantioselectivity (Table 3).

Table 3. Direct asymmetric reductive acylation of diketones ${ }^{[a]}$

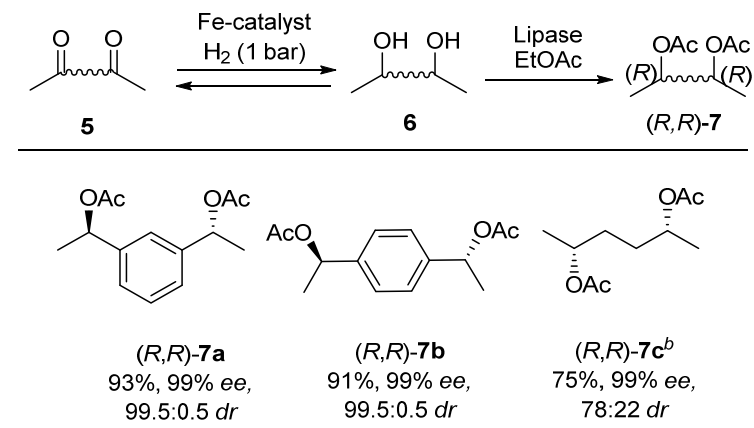

[a] Reaction conditions: 5 (0.2 mmol), catalyst 1 (20 mol\%), Novozyme-435 (12 $\mathrm{mg})$ in toluene : ethyl acetate $(1: 1,1 \mathrm{~mL})$ were stirred in a Schlenk tube at $90{ }^{\circ} \mathrm{C}$ for $6 \mathrm{~h}$; yields after isolation, ee and de of the acetates were determined by $\mathrm{GC}$ equipped with a $\beta$-dex. column.

In conclusion, we have developed a noble metal free cascade process for the conversion of pro-chiral ketones into highly enantioenriched acetates. The simple and inexpensive iron and lipase multicatalytic system operates via a hydrogenation/dynamic kinetic resolution cascade. It is important to note that the iron catalyst is not only able to reduce the ketone 
in the presence of the enzyme but additionally catalyzes the dehydrogenation of the alcohol under hydrogen atmosphere. ${ }^{17}$ Thus, a wide range of ketones, including benzylic, aliphatic, heteroaromatic and aromatic as well as diketones, were reductively acylated and the corresponding products isolated with very high yields and enantioselectivities. The newly developed protocol distinguishes itself through the absence of precious metals or expensive chiral ligands, its operational simplicity, mild reaction conditions and broad substrate scope. The good compatibility of the readily available and inexpensive iron hydrogenation/ racemization catalyst with the biocatalytic resolution calls for further application of this dual catalytic protocol. Further studies and use of this one-pot multicatalytic system are currently under investigation.

Keywords: cascade catalysis $\bullet$ kinetic resolution $\bullet$ chiral alcohols $\bullet$ racemization $\bullet$ enzyme

[1] a) B. M. Trost, Science 1991, 254, 1471; b) B. M. Trost, Angew. Chem. Int. Ed. 1995, 34, 259; c) Y. Hayashi, Chem. Sci., 2016, 7, 866; d) K. C. Nicolaou, D. J. Edmonds, P. G. Bulger, Angew. Chem. Int. Ed. 2006, 45, 7134.

[2] A. Liese, K. Seelbach, C. Wandrey, Industrial Biotransformations, 2nd, Wiely-VCH, Weinheim, Germany, 2006

[3] a) C. A. Denard, J. F Hartwig, H. Zhao, ACS Catal. 2013, 3, 2856; b) E. Garcia-Junceda, Multi-Step Enzyme Catalysis Biotransformations and Chemoenzymatic Synthesis, Wiely-VCH, Weinheim, Germany, 2008; c) J. Zhou, Multicatalyst System in Asymmetric Catalysis, Wiley-VCH, Weinheim, Germany, 2014

[4] a) J. M. J. Williams, R. J. Parker, C. Neri in Enzyme catalysis in organic synthesis: A comprehensive handbook, 2nd ed. (Eds. K. Drauz, H. Waldmann), Wiley-WCH: Weinheim, 2008, pp 287-312; b) V. GotorFernandez, R. Brieva, V. Gotor J. Mol. Catal. B: Enzym. 2006, 40, 111 c) A. S. de Miranda, L. S. M. Miranda, R. O. M. A. de Souza, Biotechnology Advances 2015, 33, 372; d) C. E. Humphrey, M. Ahmed A. Ghanem, N. J. Turner, in Application of Enzymes in Kinetic Resolutions, Dynamic Kinetic Resolutions and Deracemization Reactions, M. Todd, Ed., Wiley-VCH, Weinheim, Germany, 2014, pp 123-150; e) M. Ahmed, T. Kelly, A. Ghanem, Tetrahedron 2012, 68, 6781; f) J. Brabcova, M. Filice, M. Gutarra, J. M. Palomo, Curr. Bioact. Compd. 2013, 9, 113.

[5] a) Y. Ahn, S.-B. Ko, M.-J. Kim, J. Park, Coord. Chem. Rev. 2008, 252 647 ; b) O. Langvik, T. Saloranta, D. Y. Murzin, R. Leino, ChemCatChem, 2015, 7, 4004; c) S. Akai, Chem. Lett. 2014, 43, 746; d) M. Rachwalski, N. Vermue, F. P. J. T Rutjes, Chem. Soc. Rev. 2013, 42, 9268; e) R. Marcos, B. Martín-Matute, Isr. J. Chem. 2012, 52, 639; f) P. Hoyos, V. Pace, A. R. Alcántara, Adv. Synth. Catal. 2012, 354, 2585; g) C. Kim, J. Park, M.-J. Kim, in Comprehensive Chirality, Carreira, E. M.; Yamamoto, H. Eds., Elsevier, Amsterdam, 2012, Vol. 7, pp 156-180.

[6] For selected examples of cooperative metal and enzyme catalyzed DKR, see: a) A. L. E. Larsson, B. A. Persson, J.-E. Bäckvall, Angew. Chem. Int. Ed. 1997, 36, 1211; b) J. H. Choi, Y. H. Kim, S. H. Nam, S. T. Shin, M.-J. Kim, J. Park, Angew. Chem. Int. Ed. 2002, 41, 2373; c) B. Martín-Matute, M. Edin, K. Bogár, J.-E. Bäckvall, Angew. Chem. Int. Ed. 2004, 43, 6535; d) J. Paetzold, J.-E. Bäckvall, J. Am. Chem. Soc. 2005 127, 17620; e) A. Berkessel, M. L. Sebastian-lbarz, T. N. Müller, Angew. Chem. Int. Ed. 2006, 45, 6567; f) S. Akai, K. Tanimoto, Y. Kanao, M Egi, T. Yamamoto, Y. Kita, Angew. Chem. Int. Ed. 2006, 45, 2592; g) M. Egi, K. Sugiyama, M. Saneto, R. Hanada, K. Kato, S. Akai, Angew. Chem. Int. Ed. 2013, 52, 3654; h) R. M. Haak, F. Berthiol, T. Jerphagnon, A. J. A. Gayet, C. Tarabiono, C. P. Postema, V. Ritleng, M. Pfeffer, D. B. Janssen, A. J. Minnaard, B. L. Feringa, J. G. de Vries, J.
Am. Chem. Soc. 2008, 130, 13508; for reviews; see: i) O. Pàmies, J.-E. Bäckvall, Chem. Rev. 2003, 103, 3247; j) O. Verho, J.-E. Bäckvall, J. Am. Chem. Soc. 2015, 137, 3996.

[7] For Ru catalyzed hydrogenation followed by DKR, see: a) H. M. Jung, J.H. Koh, M.-J. Kim, J. Park, Org. Lett. 2000, 2, 409; b) H. M. Jung, J. H. Koh, M.-J. Kim, J. Park, Org. Lett. 2000, 2, 2487, c) J. A. FernándezSalas, S. Manzini, S. P. Nolan, Chem. Eur. J. 2014, 20, 13132.

[8] For selected examples of ketone reduction using ketoreductases which need to use NADPH, coupling with dehydrogenase or using the wholecell catalysis; see: a) H. Gröger, F. Chamouleau, N. Orologas, C Rollmann, K. Drauz, W. Hummel, A. Weckbecker, O. May, Angew. Chem. Int. Ed. 2006, 45, 5677; b) W. Stampfer, B. Kosjek, C. Moitzi, W Kroutil, K. Faber, Angew. Chem. Int. Ed. 2002, 41, 1014; c) M. Wolberg, W. Hummel, C. Wandrey, M. Müller, Angew. Chem. Int. Ed. 2000, 39, 4306; d) N. Kizaki, Y. Yasohara, J. Hasegawa, M. Wada, M. Kataoka, S. Shimizu, Appl. Microbiol. Biotechnol. 2001, 55, 590; e) H. Pfründer, M. Amidjojo, U. Kragl, D. Weuster-Botz, Angew. Chem. Int. Ed. 2004, 43, 4529, f) P. Xu, P.-X. Du, M.-H. Zong, N. Li, W.-Y. Lou, Scientific Reports 2016, 6, 26158.

[9] R. Millet, A. M. Träff, M. L. Petrus, J.-E. Bäckvall, J. Am. Chem. Soc. 2010, 132, 15182.

[10] a) C. Bolm, J. Legros, J. Le Paih, L. Zani, Chem. Rev. 2004, 104, 6217; b) B. Plietker, Iron Catalysis in Organic Chemistry: Reactions and applications, Wiely-VCH, ed. 2, Weinheim, Germany, 2008; c) I. Bauer, H.-J. Knölker, Chem. Rev. 2015, 115, 3170

[11] O. El-Sepelgy, N. Alandini, M. Rueping, Angew. Chem. Int. Ed. 2016, 55, 13602.

[12] For selected examples on the catalytic activity of tricarbonly iron catalysts, see: a) C. P. Casey, H. Guan, J. Am. Chem. Soc. 2007, 129 5816; b) C. P. Casey, H. Guan, J. Am. Chem. Soc. 2009, 131, 2499; c) S. Fleischer, S. S. Zhou, K. Junge, M. Beller, Angew. Chem. Int. Ed. 2013, 52, 5120; d) A. Pagnoux-Ozherelyeva, N. Pannetier, M. D. Mbaye, S. Gaillard, J.-L. Renaud, Angew. Chem. Int. Ed. 2012, 51 4976; e) T. Yan, B. L. Feringa, K. Barta, Nat. Commun. 2014, 5, 5602; f) A. J. Rawlings, L. J. Diorazio, M. Wills, Org. Lett. 2015, 17, 1086; g) H.-J. Pan, T. W. Ng, Y. Zhao, Chem. Commun. 2015, 51, 11907; h) B. Emayavaramban, M. Roy, B. Sundaraju, Chem. Eur. J. 2016, 22, 3952 i) S. Elangovan, J.-B. Sortais, M. Beller, C. Darcel, Angew. Chem. Int. Ed. 2015, 54, 14483. For selected examples on asymmetric dual catalysis; see: j) S. Zhou, S. Fleischer, K. Junge, M. Beller, Angew. Chem. Int. Ed. 2011, 50, 5120; k) A. Quintard, T. Constantieux, J. Rodriguez, Angew.Chem. Int. Ed. 2013, 52, 12883. for a review on iron catalyzed asymmetric hydrogenations: I) R. H. Morris, Chem. Soc. Rev. 2009, 38, 2282-2291; m) K. Junge, K. Schröder, M. Beller Chem. Commun., 2011, 47, 4849-4859; n) R. Bigler, R. Huber, A. Mezzetti, Synlett 2016, 27, 831; o) Y.-Y. Li, S.-L. Yu, W.-Y. Shen, J.-X. Gao, Acc. Chem. Res. 2015, 48, 2587; p) R. H. Morris, Acc. Chem. Res. 2015, 48 1494; q) F. Foubelo, C. Najera, M. Yus, Tetrahedron: Asymmetry 2015, 26, 769; r) J.-H. Xie, D.-H. Bao, Q.-L Zhou, 2015, 47, 460; s) M Yoshimura, S. Tanaka, M. Kitamura, Tetrahedron Lett. 2014, 55, 3635.

[13] For the synthesis of the iron hydride, see: a) H.-J. Knölker, E. Baum, H Goesmann, R. Klauss, Angew. Chem. Int. Ed. 1999, 38, 2064; b) T. C Johnson, G. J. Clarkson, M. Wills, Organometallics, 2011, 30, 1859. for a recent review, see: c) A. Quintard, J. Rodriguez, Angew. Chem. Int Ed. 2014, 53, 4044.

[14] a) T. Ohkuma, M. Koizumi, H. Doucet, T. Pham, M. Kozawa, K. Murata, E. Katayama, T. Yokozawa, T. Ikariya, R. Noyori, J. Am. Chem. Soc. 1998, 120, 13529; b) Q. Jiang, Y Jiang, D. Xiao, P. Cao, X. Zhang, Angew. Chem., Int. Ed. 1998, 37, 1100; c) R. Kadyrov, R. M. Koenigs, C. Brinkmann, D. Voigtlaender, M. Rueping Angew. Chem. Int. Ed. 2009, 48, 7556 - 7559; d) F. Almquist, L. Torstensson, A. Gudmundsson, T.; Frejd, Angew. Chem. Int. Ed. 1997, 36, 376; e) A. Schlatter, W.-D. Woggon, Adv. Synth. Catal., 2008, 350, 995.

[15] For selected examples on DKR of diols, see: a) B. A. Persson, F. F. Huerta, J.-E. Bäckvall, J. Org. Chem. 1999, 64, 5237; b) B. MartínMatute, M. Edin, J.-E. Bäckvall, Chem. Eur. J. 2006, 12, 6053. 
[16] Noyori hydrogenation of the $p$-diacetylbenzene gave the desired diol in only $70 \%$ de, see: T. Ohkuma, H. Ooka, S. Hashiguchi, T. Ikariya, R. Noyori, J. Am. Chem. Soc., 1995, 117, 2675.

[17] Cooperative iron and enzyme catalysis for oxidation processes see: a) H. Maid, P. Böhm, S. M. Huber, W. Bauer, W. Hummel, N. Jux, H. Gröger, Angew. Chem. Int. Ed. 2011, 50, 2397, for a recent book chapter on one-pot metal and enzymes catalysis, see: b) $\mathrm{H}$. Gröger, in Cooperative catalysis: Designing Efficient Catalysis for Synthesis, (Eds.: R. Peters), Wiley-VCH, Weinheim, 2015, pp. 325-349. 


\section{COMMUNICATION}

An iron carbonyl complex is reported to catalyze the hydrogenation of ketones and subsequent racemization of the resulting alcohols. Notably, the iron catalyzed redox reactions was combined with lipase catalyzed enantioselective acylation of the formed alcohol. The developed cooperative catalytic system was applied in the asymmetric reductive acylation of different pro-chiral ketones via a hydrogenation/dynamic kinetic resolution cascade.

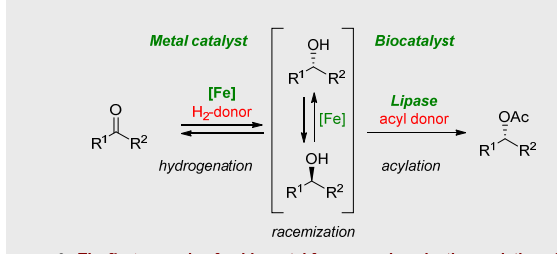

- The first example of

- The method utilizes inexpensive combined iron and lipase catalysts - Highly economic and efficient acyl and hydrogen donors
O. El-Sepelgy, *A. Brzozowska, M. Rueping*

Page No. - Page No.

Asymmetric Chemoenzymatic

Reductive Acylation of Ketones Using a Combined Iron Catalyzed Hydrogenation-Racemization and Enzymatic Resolution Cascade 